\title{
Pengaruh Media Booklet dan Film Pendek terhadap Perilaku Orangtua Balita Usia 6-24 Bulan dalam Pemberian MP-ASI
}

\author{
Nurul Laili HR*, Apoina Kartini**, Zahroh Shaluhiyah** \\ * Kementerian Kesehatan RI \\ ** Fakultas Kesehatan Masyarakat, Universitas Diponegoro \\ Email: nurulrizqie@gmail.com
}

\section{ABSTRACT}

One factor that causes malnutrition in children under five years is improper provision of complementary food. Promotion and education about complementary food is one of the effective actions to prevent malnutrition. The purpose of this study was to analyze the influence of media booklets and short films on the knowledge, attitudes, and practices of parents in the provision of complementary food. The type of this research was Quasi Experimental Research with the Nonequivalent pretestposttest research design with control group design. The population in this study were parents of children aged 6-24 months (wife and husband) in Kudus Regency with adjustment of inclusion criteria. There were 61 parents in the intervention group (gets booklets, short films, and leaflet) and 61 parents in the control group (get only leaflet). The independent variable: the provision of media booklets and short films to parents of children aged 6-24 months and the dependent variable: parental behavior (knowledge, attitudes, and practices) of parents of infants aged 6-24 months in the provision of complementary feeding. The Mann Whitney test is used to analyze data. Wife's knowledge $(p=$ 0.517), husband's knowledge ( $p=0.531)$, wife's attitude $(p=0.325)$, husband's attitude $(p=0.062)$, wife's practice
(0.052), and husband's practice ( 0.151) there was no difference in changesbetween the intervention group and the control group. However, at the mean value, the intervention group was higher than the control group in each variable. This shows that giving booklets and short films is more effective than control group.

Keywords: Complementary Food, Practice of Complementary Feeding

\section{PENDAHULUAN}

Salah satu hak anak yang didukung oleh United Nations Emergency Children's Fund (UNICEF) adalah hak untuk tetap sehat, sehingga anak memerlukan gizi, pakaian dan tempat tinggal yang sehat. ${ }^{1}$ Data World Health Organization (WHO) menyatakan, tahun 2015 terdapat 50 juta anak usia dibawah 5 tahun (7\%) yang terkena gizi buruk dan Asia Tenggara merupakan daerah dengan prevalensi tertinggi dari gizi buruk yaitu sebesar $13,5 \%$ dengan jumlah sebanyak 24 juta anak. $^{2}$ Pada tahun 2015, persentase kejadian gizi buruk balita usia 0-24 bulan di Indonesia secara nasional sebesar 3,2 persen dan menurun 0,1 persen pada tahun 2016 menjadi 3,1 persen. Akan tetapi, jika dilihat secara rinci, di Provinsi Jawa Tengah justru mengalami peningkatan persentase balita dengan gizi buruk yaitu 2,0 persen pada tahun 2015 lalu meningkat 
sebanyak 0,7 persen menjadi 2,7 persen pada tahun $2016 .^{3}$

Pendataan derajat kesehatan dinas kesehatan Provinsi Jawa Tengah, angka kasus balita gizi buruk mengalami penurunan mulai tahun 2012 sampai 2015. Akan tetapi, pada triwulan kedua tahun 2016, kasus balita gizi buruk kembali mengalami peningkatan yaitu dengan jumlah kasus sebanyak 922 pada 2015 dan bertambah menjadi 1.074 pada tahun 2016. Kabupaten Kudus disebutkan dalam data tersebut masih ditemukan kasus gizi buruk sebanyak 16 kasus. ${ }^{4}$ Salah satu faktor yang menyebabkan gizi buruk adalah pola pengasuhan orangtua. ${ }^{5,6}$ Pemberian MPASI yang tidak tepat (usia, frekuensi, dan jenisnya) mampu memberikan dampak yang berbahaya sampai kematian pada balita. Angka kematian balita masih terjadi peningkatan mulai tahun 2014. Triwulan kedua tahun 2016, sudah ditemukan angka kematian balita sebanyak 506 kasus, 9 kasus terjadi di Kabupaten Kudus. ${ }^{4}$

Dampak pemberian MP-ASI yang tidak tepat dapat memunculkan beberapa kemungkinan bahaya seperti diare, alergi, konstipasi, gangguan pencernaan lain dan sebagainya. ${ }^{7}$ Sampai saat ini, diare masih merupakan penyebab kematian yang sering terjadi pada balita setelah pneumonia. ${ }^{2} \mathrm{Di}$ Indonesia, angka kesakitan diare pada usia 6-11 bulan masih menempati urutan tertinggi kedua setelah kelompok usia 1223 bulan. ${ }^{8}$ Selain itu, pola pemberian MPASI yang tidak tepat juga mempengaruhi status gizi balita. pemberian MP-ASI juga menjadi sebuah kegiatan yang penting dan perlu diperhatikan oleh orangtua bayi disebabkan usia 6-9 bulan merupakan masa yang penting bagi bayi untuk mendapatkan stimulasi keterampilan oromotor. Jika hal ini terlewatkan, dapat dimungkinkan terjadi peningkatan kemungkinan masalah makan pada usia batita. ${ }^{9}$

Kerjasama yang baik antara suami dan istri secara bersama-sama dimungkinkan mampu mengoptimalkan usaha perbaikan derajat kesehatan. Media kombinasi antara booklet dan film digunakan karena berdasarkan penelitianpenelitian sebelumnya, kedua media tersebur diketahui mampu meningkatkan pengetahuan, yang akan memberikan efek berkepanjangan terhadap sikap dan praktik orangtua dalam memberikan MP-ASI kepada balitanya. Penggunaan booklet diharapkan mampu menjadi langkah pendidikan kesehatan yang berkelanjutan karena dapat disimpan dan dijadikan panduan ketika akan memberikan MP-ASI kepada balitanya. Keterlibatan orangtua secara lengkap serta penggunaan media yang berkelanjutan diharapkan mampu memberikan perubahan terhadap praktik pemberian MP-ASI kepada balita sehingga mampu meningkatkan derajat kesehatan balita di lingkungan penelitian ini.

\section{METODE PENELITIAN}

Jenis penelitian yang digunakan oleh peneliti adalah Eksperimental-Semu atau Quasi Eksperimental Research dengan menggunakan rancangan penelitian Nonequivalent pretest-posttest with control group design. Data dikumpulkan menggunakan kuesioner. penelitian dilaksanakan pada bulan Mei-Agustus 2018.

Populasi penelitian ini adalah seluruh orangtua balita usia 6-24 bulan di Kabupaten Kudus. Sampel dalam penelitian ini adalah 122 pasangan istri dan suami (orangtua) yang memiliki balita usia 6-24 bulan di Kabupaten Kudus. Dibagi menjadi 2 kelompok yaitu 61 orangtua balita usia 6-24 bulan di Desa Jati Wetan Kabupaten Kudus untuk kelompok perlakuan dan 61 orangtua balita usia 6-24 bulan di Desa Purwosari Kabupaten Kudus untuk kelompok tanpa perlakuan. Kelompok perlakuan mendapatkan media booklet,film pendek, dan leaflet; kelompok tanpa perlakuan mendapatkan media leaflet. Analisis data menggunakan uji Mann Whitney.

\section{HASIL DAN PEMBAHASAN}

Sebagian besar orangtua pada kelompok perlakuan (istri: 96,7\% dan 
suami: 100\%) dan kelompok tanpa perlakuan (istri: 90,2\% dan suami: 93,4\%) telah menempuh pendidikan wajib belajar 9 tahun. Usia orangtua balita pada kelompok perlakuan sebagian besar (istri: 83,6\% dan suami: $75,4 \%$ ) kurang dari 35 tahun ( $<35$ tahun), pada kelompok tanpa perlakuan, sebagian besar orangtua (istri: 70,5\% dan suami: $55,7 \%$ ) berusia kurang dari 35 tahun ( $<35$ tahun). Sebagian besar rumah tangga pada kelompok perlakuan $(67,2 \%)$ dan pada kelompok tanpa perlakuan $(75,4 \%)$ memiliki penghasilan $\geq 1.536 .785$.

Responden dalam penelitian ini sebagian besar memiliki anak $\geq 2$ (kelompok perlakuan dan kelompok tanpa perlakuan: 52,5\%). Data terkait akses informasi orangtua mengenai MP-ASI dalam penelitian ini, sebagian besar orangtua pada kelompok perlakuan (istri: 73,8\% dan suami: 55,7\%) dan kelompok tanpa perlakuan (istri: $90,2 \%$ dan suami: 67,2\%) pernah mendapatkan informasi tentang MP-ASI. Para istri mendapatkan informasi MP-ASI dari buku KIA, bidan, puskesmas, rumah sakit, dokter spesialis anak, internet dan orang terdekat (orangtua, mertua, keluarga lain, dan tetangga sekitar). Para suami mendapatkan informasi MP-ASI dari bidan, internet, dan anggota keluarga lain (orangtua, kakak/adik, sepupu, dan lainnya).

\section{Pengetahuan Orangtua dalam Pemberian MP-ASI}

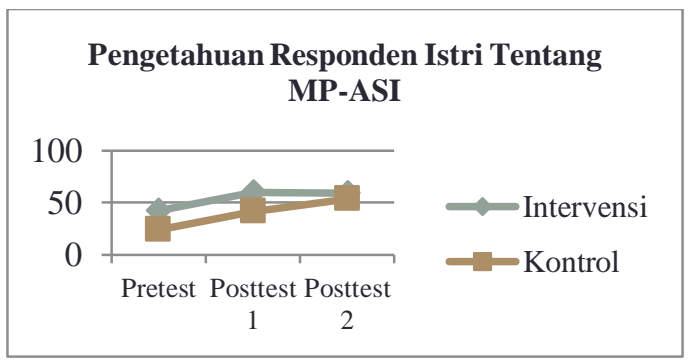

Gambar 1. Pengetahuan Responden Istri tentang MP-ASI pada kelompok Intervensi dan Kontrol
Pada responden istri dapat dilihat bahwa pada kelompok perlakuan dan kelompok tanpa perlakuan terjadi peningkatan skor pengetahuan pada saat pretest ke posttest 1 . Pada saat posttest 1 ke posttest 2, kelompok perlakuan terjadi sedikit penurunan, akan tetapi pada kelompok tanpa perlakuan tetap meningkat.

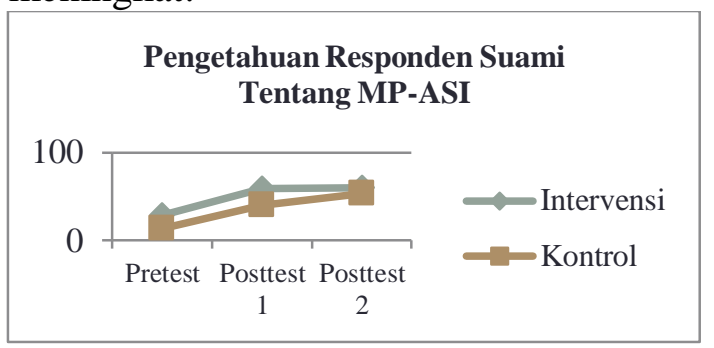

Gambar 2. Pengetahuan Responden Suami Tentang MP-ASI pada Kelompok Intervensi dan Kontrol

Skor pengetahuan pada responden suami mengalami peningkatan dari pretest, ke posttest 1, sampai pada saat posttest 2 . Peningkatan ini dialami pada kedua kelompok yaitu kelompok dengan perlakuan dan kelompok tanpa perlakuan.

Tidak terdapat perbedaan perubahan pengetahuan tentang MP-ASI yang signifikan antara kedua kelompok pada responden istri $(\mathrm{p}=0,517)$ dan responden suami $(\mathrm{p}=0,531)$. Nilai rerata/mean pada responden istri kelompok perlakuan $(3,30)$ lebih tinggi dibandingkan dengan kelompok tanpa perlakuan $(3,03)$. Pada responden suami, nilai rerata kelompok tanpa perlakuan $(3,30)$ lebih tinggi dibandingkan dengan kelompok perlakuan $(3,13)$.

Meskipun pada uji beda tidak ditemukan perbedaan perubahan, akan tetapi, jika dilihat dari skor atau nilai para responden terdapat kenaikan skor meskipun tidak signifikan.

Dilihat dari nilai rata-rata pada pengetahuan responden istri, ditemukan bahwa nilai rata-rata responden istri pada kelompok perlakuan lebih tinggi dibandingkan pada kelompok tanpa perlakuan. Hal ini menunjukkan bahwa 
pendidikan kesehatan melalui booklet dan film pendek lebih efektif dibandingkan dengan kelompok tanpa perlakuan. Hasil ini sejalan dengan sebuah penelitian yang menggambarkan bahwa pendidikan kesehatan menggunakan media audio visual (seperti: film pendek, iklan, dan lain sebagainya) berpengaruh dalam meningkatkan pengetahuan responden penelitian. ${ }^{13}$

Nilai rata-rata pada responden suami menunjukkan hal yang sebaliknya, yaitu rata-rata pada kelompok tanpa perlakuan lebih besar dibandingkan nilai rata-rata pada kelompok perlakuan. Pada kelompok tanpa perlakuan, para responden juga diberikan leaflet sebagai media pendidikan kesehatan. Hal ini sesuai pada penelitian sebelumnya yang menunjukkan bahwa media leaflet mampu memberikan pengaruh terhadap pengetahuan seseorang. ${ }^{14}$

Perbedaan keefektifan media pada responden istri dan suami ini disebabkan pada saat pemberian pendidikan kesehatan, responden suami masih menganggap bahwa hal terkait MP-ASI tidak menarik untuk mereka. Ketidaktertarikan mereka mengenai hal ini menyebabkan pada saat pemberian perlakuan, responden suami cenderung keluar masuk ruangan sehingga tidak dapat mengikuti secara menyeluruh. Pada kelompok perlakuan, meskipun mendapatkan booklet dan film pendek akan tetapi, para suami tidak memiliki antusias untuk menyimak dan mendengarkan,serta masih terdapat beberapa suami yang memiliki anggapan bahwa urusan MP-ASI cukup istri yang wajib mengetahui dan memahami.

Pada kelompok tanpa perlakuan, meskipun para suami juga sering keluar masuk ruangan, media leaflet yang lebih ringkas tetap dibaca dan memunculkan rasa ingin tahu para suami. Beberapa suami mencoba menemukan informasi lebih lanjut mengenai MP-ASI berdasarkan materi yang ada di leaflet melalui bidan dan internet. Meskipun pada uji beda menunjukkan tidak terdapat perbedaan perubahan, akan tetapi skor pengetahuan suami terkait MP-ASI pada kedua kelompok sudah baik (dengan kriteria menjawab benar $\geq 70 \%$ ).

\section{Sikap Orangtua dalam Pemberian MP- ASI pada Sebelum dan Sesudah Intervensi}

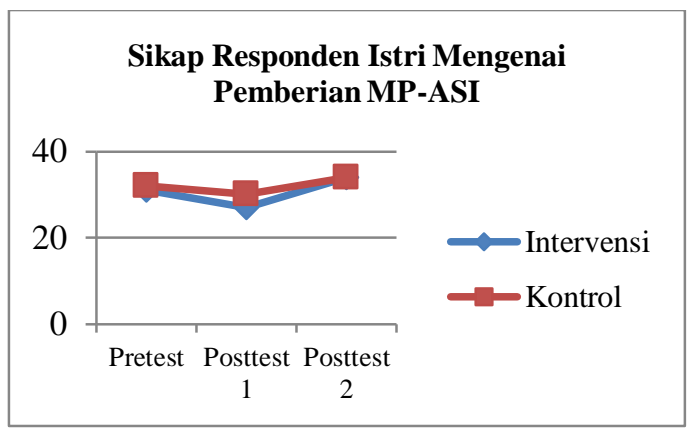

Gambar 3. Sikap Responden Istri tentang MP-ASI pada kelompok Intervensi dan Kontrol

Sikap yang mendukung terhadap pemberian MP-ASI yang tepat dan bekerjasama dengan suami pada responden istri kelompok perlakuan terjadi penurunan pada saat pretest ke posttest 1 , kemudian pada saat posttest 1 ke posttest 2 skor menjadi lebih tinggi dibandingkan pada saat pretest. Pada kelompok tanpa perlakuan, juga terjadi hal yang sama.

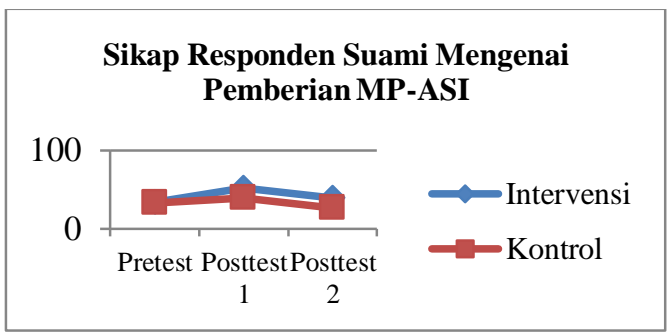

Gambar 4. Sikap Responden Suami tentang MP-ASI pada kelompok Intervensi dan Kontrol

Sikap responden suami untuk mendukung istri dalam tahap pemberian MP-ASI pada balitanya meningkat pada saat pretest ke posttest 1, kemudian dukungan menurun pada saat posttest 2 . Naik dan turunnya skor dukungan suami 
ini terjadi pada kelompok perlakuan dan kelompok tanpa perlakuan.

Tidak terdapat perbedaan perubahan sikap dalam pemberian MP-ASI yang signifikan antara kedua kelompok pada responden istri $(\mathrm{p}=0,325)$ dan responden suami $(\mathrm{p}=0,062)$. Nilai rerata/mean pada responden istri kelompok perlakuan $(6,89)$ lebih tinggi dibandingkan dengan kelompok tanpa perlakuan $(5,90)$. Pada responden suami, nilai rerata kelompok perlakuan $(7,89)$ lebih tinggi dibandingkan dengan kelompok tanpa perlakuan $(4,30)$.

penelitian ini yang tidak menunjukkan perbedaan perubahan sikap baik pada responden istri maupun responden suami dikarenakan waktu pengambilan data yang hanya berjarak setelah intervensi dilakukan dan 2 minggu setelah waktu intervensi. Jarak waktu pengambilan data posttest yang mempengaruhi hasil penelitian ini sesuai dengan penelitian terdahulu bahwa pengambilan data posttest yang dilakukan tepat setelah pemberian intervensi berpengaruh terhadap tidak adanya perbedaan perubahan skor sikap dan perilaku. ${ }^{15}$

Selain jarak pengambilan data yang menyebabkan tidak adanya perbedaan perubahan sikap, dalam penelitian ini pengalaman dan lingkungan orangtua (terutama bagi ibu) sangat berpengaruh dalam menentukan sikap orangtua dalam pemberian MP-ASI. Sikap dan kebiasaan yang nampak pada ibu yang mempunyai anak balita merupakan gambaran dari kebiasaan yang sudah muncul pada masyarakata dan secara berkelanjutan dilakukan oleh generasi selanjutnya. ${ }^{16}$

Pada penelitian ini, terlihat pada beberapa poin jawaban ibu tidak berubah dengan alasan hal tersebut sudah biasa mereka atau lingkungan mereka lakukan dan tidak menimbulkan efek negatif apapun terhadap balitanya. Misalnya pada poin pernyataan terkait dengan pemberian MP-ASI pada balita dengan usia kurang dari 6 bulan. Para ibu mengetahui bahwa memberikan MP-ASI pada usia kurang dari 6 bulan tidak baik bagi kesehatan bayi, akan tetapi, menurut para ibu, beberapa tetangga dan pada anak terdahulunya mendapatkan MP-ASI kurang dari 6 bulan dan tidak menimbulkan masalah kesehatan apapun bagi bayinya. Hal yang seperti ini yang memberikan pengaruh tidak adanya perbedaan perubahan pada sikap orangtua (terutama ibu) terkait dengan MP-ASI.

\section{Praktik Orangtua dalam Pemberian MP-ASI pada Sebelum dan Sesudah Intervensi}

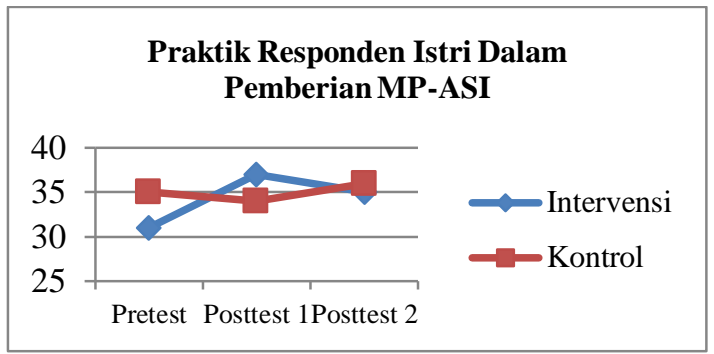

Gambar 5. Praktik Responden Istri tentang MP-ASI pada kelompok Intervensi dan Kontrol

Responden istri yang melakukan praktik pemberian MP-ASI yang baik dan tepat serta mendapatkan bantuan dari suami meningkat untuk kelompok dengan perlakuan pada saat pretest ke posttest 1, kemudian terjadi sedikit penurunan pada saat posttest 1 ke posttest 2 . Pada kelompok tanpa pelakuan, skor menurun pada saat pretest ke posttest 1 dan meningkat pada saat posstest 1 ke posttest 2.

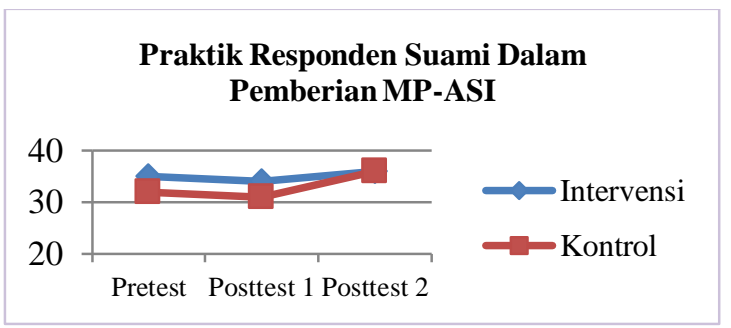

Gambar 6. Praktik Responden Suami tentang MP-ASI pada kelompok Intervensi dan Kontrol

Responden suami yang membantu istrinya dalam proses pemberian MP-ASI 
kepada balita mereka terjadi penurunan pada saat pretest ke posttest 1, kemudian responden suami yang membantu terjadi peningkatan skor pada saat posttest 1 ke posttest 2. Perubahan skor ini dialami oleh kedua kelompok yaitu kelompok perlakuan dan kelompok tanpa perlakuan.

Tidak terdapat perbedaan perubahan praktik pemberian MP-ASI yang signifikan antara kedua kelompok pada responden istri $(\mathrm{p}=0,0,52)$ dan responden suami $(\mathrm{p}=$ $0,151)$. Nilai rerata/mean pada responden istri kelompok perlakuan $(1,21)$ lebih tinggi dibandingkan dengan kelompok tanpa perlakuan $(0,77)$. Pada responden suami, nilai rerata kelompok perlakuan $(0,79)$ lebih tinggi dibandingkan dengan kelompok tanpa perlakuan $(0,38)$.

Perilaku istri dalam penelitian ini tidak terdapat perbedaan perubahan dikarenakan jarak waktu pengambilan data yang terlalu singkat didukung dengan hal-hal yang sudah menjadi kebiasaan sehingga sulit untuk merubah dalam waktu singkat. Selain itu, pada responden suami juga tidak terdapat perbedaan perubahan praktik dikarenakan para suami masih sedikit keinginan untuk terlibat dalam urusan MPASI anaknya. Peningkatan jumlah responden yang mengalami kenaikan jumlah skor baik pada praktik MP-ASI responden suami maupun istri pada posttest 2 mengalami peningkatan dibandingkan pada saat pretest. Peningkatan pengetahuan dan sikap belum tentu dapat meningkatkan praktik secara signifikan dalam waktu yang singkat. Menurut sebuah penelitian, dalam mewujudkan praktik yang sesuai dengan pengetahuan dan sikap yang positif, dibutuhkan faktor pendukung dan kondisi yang memungkinkan lainnya. ${ }^{17}$

Pemberian intervensi atau pendidikan kesehatan juga harus dilakukan secara berulang. Dalam penelitian ini, peneliti telah memberikan booklet dan leafletpada kelompok perlakuan dan leaflet pada kelompok tanpa perlakuan untuk dibawa pulang oleh masing-masing responden disertai dengan logbook untuk mengontrol pengulangan membaca, sikap, dan praktik responden. Akan tetapi, pengisian logbook tidak dilakukan oleh responden sehingga peneliti tidak bisa untuk mengontrol pembacaan media secara berulang.

Penelitian ini juga mencoba menelisik keterlibatan para suami dalam proses pemberian MP-ASI kepada balitanya. Pada situasi sebenarnya, sudah terdapat bebearapa suami yang berfikir terbuka bahwa urusan gizi dan asupan makanan balitanya tidak hanya urusan para istri, namun urusan para suami juga. Akan tetapi, masih banyak pula para responden suami yang berfikir bahwa urusan mereka adalah urusan bagaimana kebutuhan finansial keluarga dapat tercukupi, urusan pemenuhan gizi dan pemberian MP-ASI cukup diurusi oleh para istri saja. Pada dasarnya, urusan pemenuhan kebutuhan gizi anak merupakan urusan bersama antara istri dan suami. Sebuah penelitian menunjukkan bahwa keterlibatan ayah atau suami dalam lingkungan yang positif untuk membesarkan anak bersama (membentuk komitmen bersama dengan istri untuk mengurus segala kebutuhan anak bersamasama) menguatkan perilaku ibu menjadi lebih positif. ${ }^{18}$

\section{KESIMPULAN}

Nilai rata-rata perubahan variabel pengetahuan, sikap, dan praktik pada kelompok perlakuan lebih besar dibandingkan nilai rata-rata perubahan ketiga variabel pada kelompok tanpa perlakuan. Namun hasil uji statistik menunjukkan bahwa tidak terdapat perbedaan perubahan pengetahuan, sikap dan praktik pada responden istri dan suami terkait pemberian MP ASI pada kelompok perlakuan dan kelompok tanpa perlakuan.

\section{UCAPAN TERIMA KASIH}

Penulis mengucapkan terima kasih kepada Pemerintah Daerah Kabupaten Kudus dan Dinas Kesehatan Kabupaten Kudus atas ijin yang diberikan untuk melaksanakan penelitian ini. Penulis juga mengucapkan terima kasih kepada seluruh 
responden di Desa Jati Wetan dan Desa Purwosari Kabupaten Kudus atas kesediaannya berpartisipasi dalam penelitian ini.

\section{DAFTAR PUSTAKA}

1. Anggota Remaja Aulia (REMALIA). Aku Anak Dunia, Bacaan Hak-Hak Anak Bagi Anak. Jakarta: Penerbit Yayasan Aulia; 2002.

2. WHO: World Health Statistics 2016: Monitoring for the SDG's. [Internet]. 2016. [diakses pada tanggal 29 November 2017] Dari: www.who.int

3. Pusat Data dan Informasi Kementerian Kesehatan RI. Data dan Informasi Profil Kesehatan Indonesia 2016. Jakarta: Pusdatin Kemenkes RI; 2016.

4. Dinas Kesehatan Provinsi Jawa Tengah. Buku Saku Kesehatan Triwulan 2 Tahun 2016. Semarang: Dinas Kesehatan Provinsi Jawa Tengah; 2016.

5. Fujianti ST, Herawati DMD, Kadi FA. Malnourished Under-Five Children Feeding Practices in Cipacing Village 2012. Althea Medical Journal. 2015; 2 (1).

6. Saputra W, Nurrizka RH. Faktor Demografi dan Risiko Gizi Buruk dan Gizi Kurang. Makara. Desember 2012; 16 (2): 95-101.

7. Gulo MJ, Nurmiyati T. Hubungan Pemberian MPASI dengan Status Gizi Bayi Usia 6-24 bulan di Puskesmas Curug Kabupaten Tangerang. Jurnal Bina Cendekia Kebidanan. April 2015; 1 (1): 8-14.

8. Pusat Data dan Informasi Kesehatan RI. Situasi Diare di Indonesia 2011. Jakarta: Pusdatin Kemenkes RI; 2011. (new)

9. Citerawati SY, Wira Y. Makanan Pendamping ASI. Yogyakarta: Transmedika; 2016.

10. Pakhri A, Fahrizal R, Pangestu, Salmiah. Pendidikan Orang Tua, Pengetahuan Ibu, Pemberian Makanan Pendamping ASI dan Status Gizi Pada Anak Usia 6-24 Bulan di Kelurahan
Taroada Kabupaten Maros. Media Gizi Pangan. 2015; 19(1).

11. Marfua D, Kurniawati I. Hubungan Pendidikan dan Pekerjaan Ibu Terhadap Pemberian MP-ASI Dini Pada Balita Usia 6-24 Bulan. PROFESI (Profesional Islam). 2017; 15(1): 51-57.

12. Fikawati Sandra, Syafiq Ahmad. Penyebab Keberhasilan dan Kegagalan Praktik Pemberian ASI Eksklusif. Kesmas, Jurnal Kesehatan Masyarakat Nasional. 2009; 4(3): 120131.

13. Wibowo S, Suryani D. Pengaruh Promosi Kesehatan Metode Audio Visual dan Metode Buku Saku Terhadap Peningkatan Pengetahuan Penggunaan Monosodium Glutamat (MSG) Pada Ibu Rumah Tangga. Jurnal Kesmas. 2013; 7 (2): 67-74.

14. Syamsiyah Nur. Pengaruh Media Leaflet Terhadap Perubahan Pengetahuan dan Intensi Pemberian ASI Eksklusif Pada Ibu Hamil di Wilayah Puskesmas Kecamatan Pesanggrahan Jakarta Selatan Tahun 2013. Skripsi. Universitas Islam Negeri Syarif Hidayatullah Jakarta.

15. Arini FA, Sofianita NI, Ilmi IMB. Pengaruh Pelatihan Pemberian MP ASI Kepada Ibu dengan Anak Baduta di Kecamatan Sukmajaya Kota Depok Terhadap Pengetahuan dan Perilaku Pemberian MP ASI. Jurnal Kedokteran dan Kesehatan. 2017; 13(1): 80-89.

16. Maryani Endang, Ananingsih Intin. Hubungan Jenjang Pendidikan Ibu dengan Kebiasaan Memberikan MPASI. Jurnal Ners dan Kebidanan. 2014; 1(2): 126-131.

17. Said RM, Thaha MR, Syafar M. KIE untuk Peningkatan Pengetahuan, Sikap, dan Praktik Pencegahan dan Penanggulangan Penyakit Flu Burung di Kabupaten Gowa, Sulawesi Selatan. Kesmas, Jurnal Kesehatan Masyarakat Nasional. 2010; 5(1): 23-28.

18. Bilal Selamawit, Spigt M, Czabanowska K, Mulugeta A, Blanco 
R, Dinant G. Father's Perception, Practice, and Challenges in Young Child Care and Feeding in Etiopia.

Food and Nutrition Bulletin. 2016; 37(3): 329-339 